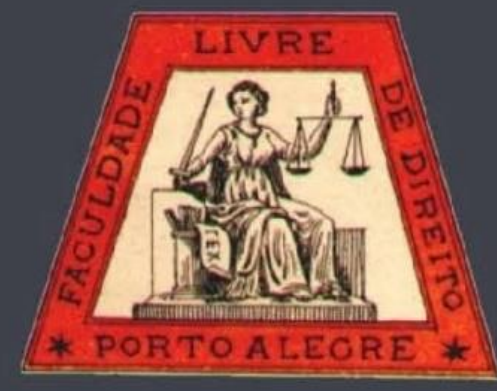

\title{
Lei de Abuso de Autoridade (PLS 85/2017 - PL 7.596/2017) frente ao direito à independência judicial
}

Abuse of Authority Act (PLS 85/2017 - PL 7.596/2017) facing the right to judicial independence

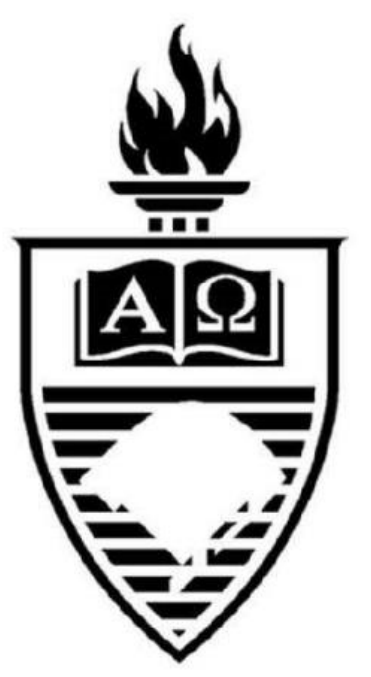

\section{Claudia Maria Barbosa}

\author{
Pontifícia Universidade Católica do Paraná
}

Gilberto Andreassa Junior

Pontifícia Universidade Católica do Paraná

\section{UFRGS}




\title{
Lei de Abuso de Autoridade (PLS 85/2017 - PL 7.596/2017) frente ao direito à independência judicial
}

\author{
Abuse of Authority Act (PLS 85/2017 - PL 7.596/2017) facing the right to judicial independence
}

\author{
Claudia Maria Barbosa* \\ Gilberto Andreassa Junior ${ }^{* *}$
}

\section{REFERÊNCIA}

BARBOSA, Claudia Maria; ANDREASSA JUNIOR, Gilberto. Lei de Abuso de Autoridade (PLS 85/2017 - PL 7.596/2017) frente ao direito à independência judicial. Revista da Faculdade de Direito da UFRGS, Porto Alegre, n. 37, p. 263-277, dez. 2017.

\section{RESUMO}

O presente artigo aborda a complexidade que envolve a independência judicial em contraposição ao projeto de lei que define os crimes de abuso de autoridade. Após um histórico acerca da teoria da separação dos Poderes, foi descrito o modo como foi recepcionada a independência do Poder Judiciário no ordenamento jurídico brasileiro. Neste contexto, ao final do texto foram analisados os tópicos mais importantes do PLS 85/2017 (PL 7.596/2017). Assim, diante da referida problematização, buscou-se, com base na doutrina e na lei, ainda que sucintamente, evidenciar a importância de uma nova lei que limitará, tão somente, atuações políticas e ilegais por parte dos magistrados. No que tange ao método utilizado (hipotético-dedutivo), este ocorre com revisão bibliográfica e estudo de casos.

\section{PALAVRAS-CHAVE}

Abuso de autoridade. Independência judicial. Separação dos Poderes.

\section{ABSTRACT}

This article addresses the complexity surrounding judicial independence as opposed to the act that defines crimes of abuse of authority. After a history about the theory of the separation of Powers, it was described how the independence of the Judiciary was received in the Brazilian legal system. In this context, the most important topics of PLS 85/2017 (PL 7.596/2017) have been analyzed at the end of the text. Thus, given the aforementioned problematization, it was sought, based on legal doctrine and on the aforementioned act, although succinctly, to highlight the importance of a new act that will restrain, only, political and illegal actions by the magistrates. Regarding the method used (hypotheticaldeductive), it is applied with a bibliographic review and case study.

\section{KEYWORDS}

Abuse of authority. Judicial Independence. Separation of Powers.

\section{SUMÁRIO}

Introdução. 1. Independência judicial aos olhos da Teoria do Estado e do Direito. 1.1. A teoria da separação dos Poderes: do estado liberal ao estado democrático de direito, do positivismo à politização da justiça. 1.2. A independência judicial no Brasil. 2. Lei de Abuso de Autoridade (PLS 85/2017 - PL 7.596/2017). Conclusão. Referências.

\footnotetext{
* Pós-doutora em Direito pela York University, Canadá. Doutora e Mestre em Direito pela Universidade Federal de Santa Catarina (UFSC). Professor titular de Direito Constitucional da Pontifícia Universidade Católica do Paraná (PUC-PR).

** Doutorando em Direito pela Pontifícia Universidade Católica do Paraná (PUC-PR). Mestre em Direito pela UniBrasil. Membro honorário da Academia Brasileira de Direito Processual Civil.
} 


\section{INTRODUÇÃO}

Ultimamente, muito se discute acerca do projeto de lei que define os crimes de abuso de autoridade. Há, na visão de muitos, uma incompatibilidade entre o projeto apresentado e aprovado no Senado Federal, e a prerrogativa dos magistrados à independência em face de aspectos externos e internos.

$\mathrm{O}$ artigo procura responder ao seguinte questionamento: com a promulgação da lei de abuso de autoridade (PLS 85/2017 - PL 7.596/2017), restará afetada a independência judicial?

Em momento inicial, através de uma análise histórica, será abordada a teoria da separação dos Poderes, isto é, será descrito o movimento do Estado Liberal ao Estado Democrático de Direito, do positivismo jurídico à politização da justiça.

Constata-se que a atividade política da jurisdição constitucional se realiza, na atualidade, a partir de um desenho institucional que viabiliza o exercício desta atividade.

Mais à frente, busca-se demonstrar como funciona a questão da independência judicial no Brasil.

A partir da segunda metade do século XX, foi de fundamental importância assegurar aos magistrados total independência em suas decisões, sobretudo porque muitas delas teriam impacto nos demais Poderes.

A independência das Cortes de Justiça foi influenciada pela Declaração Universal dos Direitos Humanos e é resultado de uma longa construção que teve como objetivo a garantia do direito de minorias e a concretização de direitos fundamentais.

Promulgada em 1979, a Lei Orgânica da Magistratura Nacional reforçou a ideia de que a atuação dos juízes deveria ser imparcial e independente. Ademais, já estando em vigor a Constituição Federal de 1988, tem-se a independência judicial como algo inerente e fundamental para atuação da magistratura.

Neste contexto, e adentrando ao final do ensaio, procura-se analisar os aspectos mais relevantes da lei de abuso de autoridade, chegando-se à conclusão de que não há, em um único artigo do projeto, dispositivo que prejudique e interfira na independência judicial, ou fundamento que desrespeite normas constitucionais e infraconstitucionais.

No que toca ao método adotado para a investigação (hipotético-dedutivo), este se dará com revisão bibliográfica e estudo de casos.

\section{INDEPENDÊNCIA JUDICIAL AOS OLHOS DA TEORIA DO ESTADO E DO DIREITO}

É possível afirmar que a independência judicial, nos moldes que é vista atualmente, surgiu de uma nova ordem constitucional delineada, principalmente, no período pósguerra. Verificou-se, após um tempo de defesa ao positivismo jurídico, ou melhor, à legalidade extrema, a necessidade de interpretação das normas por parte dos magistrados, a fim de garantir direitos de minorias e de se concretizar direitos fundamentais.

Esta possível interpretação da lei gera a necessidade de uma efetiva independência aos juízes, fato constatado e defendido na Lei Orgânica da Magistratura Nacional (Lei Complementar $\mathrm{n}^{\circ}$ 35/1979) ${ }^{1}$ e na própria Constituição Federal de $1988 .{ }^{2}$ Referido tema,

\footnotetext{
${ }^{1}$ Ex. Artigo 41, da Lei Complementar no 35/1979: Salvo os casos de impropriedade ou excesso de linguagem o magistrado não pode ser punido ou prejudicado pelas opiniões que manifestar ou pelo teor das decisões que proferir.

${ }^{2}$ Aqui, não há previsão expressa. Todavia, através de uma leitura moral da Constituição Federal, percebe-se que, implicitamente, esta foi a ideia da Constituinte. Nas palavras de PETER RUSSELL, fato semelhante ocorre no Reino Unido, Israel e Nova Zelândia. (RUSSELL, Peter H. Toward a general theory of judicial independence. Judicial independence in the age of democracy: critical
} 
inclusive, possui íntima relação com o que se chama de ativismo judicial, judicialização da política $^{3}$ e politização da justiça.

Pois bem. Feita a introdução, faz-se necessário um breve relato histórico acerca da separação dos Poderes. Após, será analisada a independência judicial no Brasil.

1.1 A teoria da separação dos poderes: do Estado Liberal ao Estado Democrático de Direito, do positivismo à politização da justiça

A atividade política da jurisdição se realiza, hodiernamente, a partir de um desenho institucional que viabiliza o exercício desta atividade. Porém, nem sempre foi assim, conforme se verifica a seguir.

O princípio da separação dos Poderes foi elaborado, como teoria política, na obra de John Locke (1689). ${ }^{4}$ Em período próximo e com parecidos ideais, nasce o discurso de Montesquieu (1748). ${ }^{5}$ Para ambos, a teoria da separação dos Poderes foi concebida para assegurar a existência de um governo moderado, mediante distribuição das atividades do Estado e

perspectives from around the world. The University Press of Virginia, 2001, p. 22).

3 "A judicialização, como demonstrado acima, é um fato, uma circunstância do desenho institucional brasileiro. Já o ativismo é uma atitude, a escolha de um modo específico e proativo de interpretar a Constituição, expandido o seu sentido e alcance". (BARROSO, Luís Roberto. O controle de constitucionalidade no direito brasileiro. 6. ed. rev. e atual. São Paulo: Saraiva, 2012, p. 372). Ainda, "não obstante ser um fenômeno atual, o discurso muitas vezes confunde a ideia de judicialização da política com a ideia genérica de ativismo judicial, tanto que se tem utilizado o termo de judicialização de megapolítica (ou de macropolítica) para distingui-lo da judicialização da política genérica". (BARBOZA, Estefânia Maria de Queiroz; KOZICKI, Katya. Judicialização da política e controle judicial de políticas públicas. Rev. direito $G V$ [online], v. 8, n.1, p. 61, 2012).

${ }^{4}$ LOCKE, John. Dois tratados sobre o governo. Tradução de Julio Fischer. São Paulo: Martins Fontes, 1998.

5 MONTESQUIEU, Charles de Secondat, Barão de. $O$ espírito das leis. Tradução de Pedro Vieira Mota. 9. ed. São Paulo: Saraiva, 2008. consequente controle recíproco entre suas formas de expressão.

A teoria somente foi concebida em contraposição ao absolutismo defendido por Thomas Hobbes (1651). ${ }^{6}$ Para o autor, o poder é exercido pelo soberano (monarca) mediante a submissão dos indivíduos e é usado para reprimir os conflitos humanos.

Superando a ideia de Hobbes, Montesquieu afirma que nenhuma sociedade sem governo pode subsistir, discorrendo sobre a importância das leis para a garantia da vida em sociedade. $^{7}$

Portanto, a teoria da separação dos Poderes foi concebida para assegurar a existência de um governo moderado, mediante distribuição de atividades do Estado e consequente controle recíproco entre suas formas de expressão. Tratase da tentativa de contenção do poder pelo poder.

Percebe-se, nos estudos de Locke e Montesquieu, que a teoria da separação dos Poderes foi elaborada e sustentada a fim de conferir proteção aos direitos fundamentais de primeira geração contra as iniciativas arbitrárias do Estado. Ou seja, as concepções dos autores acabaram por influenciar as Constituições liberais.

O modelo do constitucionalismo liberal preocupava-se exclusivamente em proteger $\mathrm{o}$ indivíduo da ingerência do Estado:

A teoria do Estado com poderes divididos
conquistou prestígio na doutrina constitucional
do liberalismo porque se consolidou como
importante mecanismo de garantia das
liberdades individuais ou mais precisamente
como penhor dos recém-adquiridos direitos
políticos da burguesia frente ao antigo poder das
realezas absolutas. O liberalismo foi a doutrina
política que fundamentou a construção da teoria
do Estado e do Direito. Um Estado
juridicamente limitado pela Constituição e
ideologicamente assumido pela doutrina liberal.

${ }^{6}$ HOBBES, Thomas. Leviatã. São Paulo: Martin Claret, 2006.

${ }^{7}$ MONTESQUIEU, Charles de Secondat, Barão de. op. cit., p. 83-86. 
Cuidava-se de garantir a liberdade do indivíduo e da sociedade frente ao Estado (...). Ao Estado liberal, sempre juridicamente controlado, não cabe exercer mais do que as seguintes atividades; manter a ordem interna e conduzir a política exterior. ${ }^{8}$

Não obstante, o pensamento abordado foi alterado com a Revolução Industrial e com o surgimento do sufrágio universal. Na realidade, o enfraquecimento do Estado Liberal começa quando as grandes empresas começam a ser monopolistas e aniquilam a concorrência. Neste ponto surge o proletariado que prega um Estado Social - também chamado de Estado Providência, Estado de Serviço, ou Welfare State - contra a autorregulação do mercado. ${ }^{9}$ A ação do Estado torna-se imprescindível para a correção dos desvios existentes no meio social.

$\mathrm{Na}$ visão da doutrina, "a transição entre Estado Liberal e o Estado Social promove alteração substancial quanto à concepção de Estado e de sua finalidade". ${ }^{10}$

Junto com este Estado social nasce um novo sistema ético de referência, baseado na proteção dos direitos humanos. Inclusive, a partir de 1948 - época em que já se fazia presente em diversos países o Estado Social -, com a assinatura da Declaração Universal dos Direitos Humanos, os Estados se comprometeram a assegurar novos bens da vida, indispensáveis para a sobrevivência da humanidade. ${ }^{11}$

Destarte, a estabilidade objetivada no Estado Liberal é substituída pelo dirigismo

\footnotetext{
8 CLÈVE, Clèmerson Merlin. Atividade legislativa do Poder Executivo. 3. ed. rev. atual. e ampl. São Paulo: Revista dos Tribunais, 2011, p. 34-35.

9 "A crise recorrente do capitalismo, o sufrágio universal, as reivindicações da classe operária, as revoluções socialistas, a passagem da empresa individual para a coletiva e da concorrência para o oligopólio, a emergência da sociedade de massas e a consequente urbanização pela qual passou o mundo, esses dados todos, somados a outros, concluíram por forçar o nascimento de um novo tipo de Estado". (Ibidem, p. 40).

10 CANELA JUNIOR, Osvaldo. Controle judicial de políticas públicas. São Paulo: Saraiva, 2011, p. 70.

${ }^{11}$ Ibidem, p. 71.
}

estatal, alterando-se a concepção da teoria da separação dos Poderes:

\begin{abstract}
No Estado liberal, o objetivo da teoria da separação dos poderes, consoante já assentado, era o de evitar a concentração do poder estatal, a fim de que os direitos fundamentais de primeira geração fossem assegurados. O Estado, na premissa liberal, é um elemento catalisador do poder, instrumento para a sua contenção, em estrito respeito à liberdade individual. No Estado social, este objetivo permanece, mas a ele é acrescentado o desiderato de realização dos direitos fundamentais de segunda e outras gerações, com o propósito de se assegurar a igualdade substancial entre os cidadãos. De uma conduta meramente negativa, passiva, o Estado assume, também, uma conduta pró-ativa. ${ }^{12}$
\end{abstract}

\section{Como consequência deste Estado}

Social, surge a nomenclatura do Estado Democrático de Direito, a qual perdura até a presente data no Brasil. ${ }^{13}$

Percebe-se que "a separação foi historicamente necessária quando o poder pendia entre governantes que buscavam recobrar suas prerrogativas absolutas e pessoais e o povo que, representado nos parlamentos, intentava dilatar sua esfera de mando e participação na gerência dos negócios públicos"14. ${ }^{15}$

Outra teoria da separação dos Poderes foi elaborada por Alexander Hamilton, James Madison e John Jay, os quais escreveram e publicaram 85 artigos argumentando favoravelmente em relação à promulgação da Constituição Norte Americana. A coletânea destes trabalhos deu origem ao livro "O

\footnotetext{
12 Ibidem, p. 72.

${ }^{13}$ Estado Democrático de Direito: Fundado não mais no princípio da legalidade, mas no princípio da constitucionalidade. Ademais, não só procura garantir a liberdade, mas também a igualdade.

14 BONAVIDES, Paulo. Ciência política. 10. ed. 13. tiragem. São Paulo: Malheiros, 2004, p. 146.

${ }^{15}$ Percebe-se, pela leitura histórica, que no Estado Liberal havia uma preeminência do Poder Legislativo, enquanto que no Estado Social havia uma supremacia do Poder Executivo. Já no Estado Constitucional, prevalece, de certa forma, os mandamentos do Poder Judiciário.
} 
Federalista", razão porque os autores são chamados de "Os Federalistas". ${ }^{16}$

Referidos autores defendiam a harmonia entre os Poderes e afirmavam que não seria necessária uma independência, mas sim uma interdependência entre as funções do Estado.

$\mathrm{Na}$ atualidade, parece claro que se deve trabalhar com a máxima efetividade da Constituição e com a harmonia (pesos e contrapesos - check and balance) entre os Poderes. Isto, inclusive, remete ao art. $2^{\circ}$ da Constituição Federal que descreve: "São Poderes da União, independentes e harmônicos entre si, o Legislativo, o Executivo e o Judiciário".

Paulo Bonavides afirma que "numa idade em que o povo organizado se fez o único e verdadeiro poder e o Estado contraiu na ordem social responsabilidades que o Estado liberal jamais conheceu, não há lugar para a prática de um princípio rigoroso de separação". ${ }^{17}$

Bruce Ackerman, na mesma linha de pensamento, delimita que "a separação dos poderes é uma boa ideia, mas não há nenhuma razão para supor que os escritores clássicos esgotaram a sua excelência". ${ }^{18}$

Com base nas notas anteriores, em especial na máxima efetividade da Constituição, pode-se afirmar o porquê da judicialização/ativismo ter se tornado parte significativa e integrante do ordenamento jurídico brasileiro.

A tendência para a constitucionalização de direitos e a fortificação do Judiciário demonstra-se como um produto inevitável de uma universal priorização dos direitos humanos após a Segunda Guerra Mundial. Democracia não é equivalente à regra

16 HAMILTON, Alexander; JAY, John; MADISON, James. O Federalista. 2. ed. Campinas: Russel Editores, 2005.

${ }^{17}$ BONAVIDES, Paulo. Op. cit., p. 146.

18 ACKERMAN, Bruce. A nova separação de poderes. Tradução de Isabelle Maria Campos Vasconcelos e Eliana Valadares Santos. Rio de Janeiro: Lumen Juris, 2009, p. 113. da maioria. Em uma real democracia, as minorias devem estar protegidas através de uma Constituição escrita, cabendo aos juízes, que não estão sujeitos às pressões dos partidos políticos, aplicar estes direitos, ainda que de forma ativista. $^{19}$

Mauro Cappelletti discorre que a criatividade constitui um fator inevitável da função jurisdicional, o que não torna os julgadores, necessariamente, legisladores. De fato, os juízes estão constrangidos a ser criadores do direito, law makers. "Efetivamente, eles são chamados a interpretar e, por isso, inevitavelmente a esclarecer, integrar, plasmar e transformar, e não raro a criar ex novo o direito". ${ }^{20}$

Já adentrando ao século XXI - ao que parece, ainda no Estado Democrático de Direito -, percebe-se que o Poder Judiciário, tomado por um sentido popular e midiático de justiça, começa não só a atuar de forma ativista, mas sim de forma política (politização da justiça), ainda que em algumas situações isto gere o afastamento da lei. ${ }^{21}$

\subsection{A independência judicial no Brasil}

Através de um formato constitucional que possibilita o exercício ativista/político por parte do Judiciário, se fez necessário, a partir da segunda metade do século $\mathrm{XX}$, assegurar aos magistrados total independência em suas

${ }^{19}$ HIRSCHL, Ran. Towards juristocracy: the origins and consequences of the new constitutionalism. Harvard University Press, 2007.

20 CAPPELLETTI, Mauro. Juízes legisladores? Porto Alegre: Sérgio Antonio Fabris Editor, 1999, p. 73-74.

${ }^{21}$ Para PEDRO SERRANO, o Estado de Exceção "estará presente na jurisdição quando suas decisões se apresentarem como mecanismos de desconstrução do direito, com finalidade eminentemente política, seja pela suspensão da própria democracia, seja pela suspensão de direitos da sociedade ou parcela dela, como de fato ocorreu e ainda ocorre no Brasil em inúmeras situações". (SERRANO, Pedro Estevam Alves Pinto. Autoritarismo e golpes na América Latina: breve ensaio sobre jurisdição e exceção. São Paulo: Alameda, 2016, p. 104). 
decisões, sobretudo porque muitas delas teriam impacto nos Poderes Executivo e Legislativo.

A independência das Cortes de Justiça, no Brasil, foi influenciada pela Declaração Universal dos Direitos Humanos (1948) ${ }^{22}$ e é resultado de uma longa construção que teve como desiderato principal a garantia do direito de minorias e a concretização de direitos fundamentais. Além disso, na origem, a independência judicial significou a emancipação do Judiciário face ao Executivo, na busca de uma superação da chamada "justiça de gabinete". ${ }^{23}$

A Lei Orgânica da Magistratura Nacional, promulgada em 14 de março de 1979, reforçou a ideia de que a atuação dos juízes deveria ser imparcial e independente. Inclusive, passado certo período histórico e já estando em vigor a Constituição Federal de 1988, delimita-se a independência judicial como algo inerente e fundamental para atuação da magistratura.

A independência judicial é estabelecida constitucionalmente de duas formas distintas: objetivamente, a independência se dá com fundamento no art. $2^{\circ}$, da Constituição Federal (relação entre os Poderes); subjetivamente, a independência se dá em relação aos seus próprios membros. Aqui, pode-se estabelecer um aspecto externo e outro interno. Exteriormente, todo juiz é independente perante a administração pública e os demais Poderes. Já internamente, os juízes são independentes entre si, não havendo subordinação - ressalvando-se os casos previstos em lei onde os juízes devem seguir,

\footnotetext{
${ }^{22}$ Art. $10^{\circ}$ da DUDH: Toda a pessoa tem direito, em plena igualdade, a que a sua causa seja equitativa e publicamente julgada por um tribunal independente e imparcial que decida dos seus direitos e obrigações ou das razões de qualquer acusação em matéria penal que contra ela seja deduzida.

${ }^{23}$ Vale mencionar que a independência do Poder Judiciário já era defendida por Rui Barbosa no fim do século XIX. Extrai-se da revisão criminal $n^{\circ} 215$ que a criminalização da interpretação do Direito "faria da toga a mais humilde das profissões servis". (Rui Barbosa. Obras Completas. v.
} XXIII, t. III, p. 228). obrigatoriamente, orientação jurisprudencial dos tribunais superiores.

Antoine Garapon já afirmara que, "tradicionalmente, distinguem-se a independência externa, qual seja, a liberdade de que goza globalmente a magistratura em comparação com outros órgãos políticos, e a independência interna, aquela de que gozam os membros dentro de sua corporação". ${ }^{24}$

A Constituição Federal também garante aos juízes e representantes do Ministério Público as prerrogativas da vitaliciedade, inamovibilidade e irredutibilidade de subsídio (art. 95). Ainda, classifica como crime de responsabilidade os atos do Presidente da República que atentem contra o livre exercício do Poder Judiciário (art. 85, II).

Aprovado na $68^{\mathrm{a}}$ sessão ordinária do Conselho Nacional de Justiça, no dia 06 de agosto de 2008, o Código de Ética da Magistratura Nacional também confere alguns itens acerca da independência judicial: ${ }^{25}$

Art. $1^{\circ} \mathrm{O}$ exercício da magistratura exige
conduta compatível com os preceitos deste
Código e do Estatuto da Magistratura,
norteando-se pelos princípios da independência,
da imparcialidade, do conhecimento e
capacitação, da cortesia, da transparência, do
segredo profissional, da prudência, da
diligência, da integridade profissional e pessoal,
da dignidade, da honra e do decoro.

Art. $4^{\mathrm{o}}$ Exige-se do magistrado que seja eticamente independente e que não interfira, de qualquer modo, na atuação jurisdicional de outro colega, exceto em respeito às normas legais.

Art. $5^{\circ}$ Impõe-se ao magistrado pautar-se no desempenho de suas atividades sem receber indevidas influências externas e estranhas à justa convicção que deve formar para a solução dos casos que lhe sejam submetidos.

24 GARAPON, Antoine. $O$ juiz $e$ a democracia: o guardião das promessas. 2. ed. Rio de Janeiro: Revan, 2001, p. 60.

${ }_{25}$ Disponível

<http://www.cnj.jus.br/publicacoes/codigo-de-etica-damagistratura>. Acesso em: 24 jul. 2017. 
Art. $6^{\circ}$ É dever do magistrado denunciar qualquer interferência que vise a limitar sua independência.

Art. $7^{\circ} \mathrm{A}$ independência judicial implica que ao magistrado é vedado participar de atividade político-partidária.

Art. 17 É dever do magistrado recusar benefícios ou vantagens de ente público, de empresa privada ou de pessoa física que possam comprometer sua independência funcional.

Fica evidenciado que a independência do Poder Judiciário brasileiro - e dos seus próprios membros - constitui um pressuposto para que a atividade jurisdicional alcance a completa legitimidade democrática. Mais do que resguardar uma classe específica, a independência foi pensada com $\mathrm{o}$ fito de beneficiar a sociedade, haja vista que automaticamente gera maior imparcialidade do julgador. ${ }^{26}$

\section{LEI DE ABUSO DE AUTORIDADE (PLS 85/2017 - PL 7.596/2017)}

Pouco se questiona sobre a necessidade de independência ao Poder Judiciário, sobretudo porque algumas de suas decisões estão intimamente ligadas aos demais Poderes (Executivo e Legislativo). A vitaliciedade, inamovibilidade e irredutibilidade de subsídio são peças primordiais para que o juiz atue livre de interferências externas e internas.

$O$ ponto de perigo na questão da independência ocorre, primeiramente, quando o processo de promoção na carreira especialmente na busca de uma cadeira no Supremo Tribunal Federal - está vinculado às

26 MAURO CAPPELLETTI, em sua obra "Juízes irresponsáveis?", cita a opinião de Giovanni Pugliese quando afirma que "a independência não é senão o meio dirigido a salvaguarda outro valor - conexo certamente, mas diverso e bem mais importante do que o primeiro -, ou seja, a imparcialidade do juiz". (CAPPELLETTI, Mauro. Juízes irresponsáveis? Porto Alegre: Sérgio Antonio Fabris Editor, 1989, p. 32). indicações políticas. Ademais, quão independente pode ser um Poder sem minar o Estado de Direito? ${ }^{27}$ Quais seriam os limites à atuação dos magistrados? Como se deve proceder quando um agente público atua em desacordo com a lei ou, simplesmente, de forma abusiva/autoritária? ${ }^{28}$

$\mathrm{Na}$ ânsia de responder aos questionamentos e buscando a efetiva consolidação do Estado de Direito, em março de 2017 foi proposto no Senado Federal um projeto de lei que define os crimes de abuso de autoridade no Brasil. De autoria do Senador Randolfe Rodrigues, o projeto foi autuado sob o $n^{\circ} 85 / 2017$ e teve ampla defesa da maioria dos políticos.

${ }^{27}$ Por mais paradoxal que possa parecer, a imunidade do juiz - que não é saudável ao Estado de Direito - surge a partir de uma absoluta proteção à independência diante de pressões externa e internas. (Ibidem, p. 33).

${ }^{28}$ Ainda em vigor, a Lei $\mathrm{n}^{\mathrm{o}} 4.898 / 65$, que regula o direito de representação nos casos de abuso de autoridade, em seus artigos $3^{\circ}$ e $4^{\circ}$, considera abuso qualquer atentado: a) à liberdade de locomoção; b) à inviolabilidade do domicílio; c) ao sigilo da correspondência; d) à liberdade de consciência e de crença; e) ao livre exercício do culto religioso; f) à liberdade de associação; g) aos direitos e garantias legais assegurados ao exercício do voto; h) ao direito de reunião; i) à incolumidade física do indivíduo; j) aos direitos e garantias legais assegurados ao exercício profissional. Constitui também abuso de autoridade: a) ordenar ou executar medida privativa da liberdade individual, sem as formalidades legais ou com abuso de poder; b) submeter pessoa sob sua guarda ou custódia a vexame ou a constrangimento não autorizado em lei; c) deixar de comunicar, imediatamente, ao juiz competente a prisão ou detenção de qualquer pessoa; d) deixar o Juiz de ordenar o relaxamento de prisão ou detenção ilegal que lhe seja comunicada; e) levar à prisão e nela deter quem quer que se proponha a prestar fiança, permitida em lei; f) cobrar o carcereiro ou agente de autoridade policial carceragem, custas, emolumentos ou qualquer outra despesa, desde que a cobrança não tenha apoio em lei, quer quanto à espécie quer quanto ao seu valor; g) recusar o carcereiro ou agente de autoridade policial recibo de importância recebida a título de carceragem, custas, emolumentos ou de qualquer outra despesa; h) o ato lesivo da honra ou do patrimônio de pessoa natural ou jurídica, quando praticado com abuso ou desvio de poder ou sem competência legal; i) prolongar a execução de prisão temporária, de pena ou de medida de segurança, deixando de expedir em tempo oportuno ou de cumprir imediatamente ordem de liberdade. 
A proposta causou diversas manifestações na sociedade e, acima de tudo, foi criticada por representantes do Ministério Público e da magistratura, pois estes acreditam em uma tentativa de freamento da Operação "Lava Jato". Ainda assim, houve aprovação no Plenário da Casa (54 votos a 19) e, no momento, se encontra na Câmara dos Deputados (PL 7.596/2017).

Necessário ressalvar que a maioria das críticas se fundava no chamado "crime de hermenêutica" e na possibilidade de qualquer cidadão aforar as demandas em face dos agentes públicos.

Aberto ao debate, o Senado Federal acatou alguns dos pedidos da Procuradoria-Geral da República, isto é, houve concordância na retirada de trechos do projeto que permitissem a criminalização da hermenêutica, ou seja, a punição de juízes cujas sentenças fossem reformadas. Também foi retirada do texto a possibilidade de vítimas de abuso de autoridade ajuizar ação privada mesmo antes de eventual ação penal pública.

Os principais crimes que estão presentes no Projeto de Lei 7.596/2017 são os seguintes: decretação de medida de privação da liberdade em manifesta desconformidade com as hipóteses legais; decretação de condução coercitiva de testemunha ou investigado manifestamente descabida ou sem prévia intimação de comparecimento ao juízo; constranger em depoimento, sob ameaça de prisão, pessoa que, em razão de função, ministério, ofício ou profissão, deva guardar segredo ou resguardar sigilo; impedir, sem justa causa, a entrevista pessoal e reservada do preso com seu advogado; proceder à obtenção de prova, em procedimento de investigação ou fiscalização, por meio manifestamente ilícito; induzir ou instigar pessoa a praticar infração penal com o fim de capturá-lo em flagrante delito, fora das hipóteses previstas em lei; divulgar gravação ou trecho de gravação sem relação com a prova que se pretenda produzir, expondo a intimidade ou a vida privada, ou ferindo honra ou a imagem do investigado ou acusado; demorar demasiada e injustificadamente no exame de processo de que tenha requerido vista em órgão colegiado, com o intuito de procrastinar seu andamento ou retardar o julgamento; e antecipar o responsável pelas investigações, por meio de comunicação, inclusive rede social, atribuição de culpa, antes de concluídas as apurações e formalizada a acusação.

Nas disposições finais o projeto ainda traz os seguintes crimes: realizar interceptação de comunicações telefônicas, de informática ou telemática, promover escuta ambiental ou quebrar segredo da Justiça, sem autorização judicial ou com objetivos não autorizados em lei; e violar direito ou prerrogativa de advogado.

Entre os efeitos da condenação previstos estão obrigação de indenizar, inabilitação para exercício de cargo público por até cinco anos (reincidência) e perda do cargo (reincidência) (Art. $4^{\circ}$ ). Também, as penas previstas nesta lei serão aplicadas independentemente das sanções de natureza civil ou administrativa porventura cabíveis (Art. $6^{\circ}$ ).

Os crimes previstos na lei são de ação penal pública incondicionada. Por outro lado, será admitida ação privada se a ação penal pública não for intentada no prazo legal (Art. $\left.3^{\circ}\right)$.

Constata-se, destarte, que não há, no Projeto de Lei, qualquer artigo que prejudique e/ou interfira na independência judicial. Atuando dentro do que delimita a lei, ${ }^{29}$ dificilmente haverá qualquer tipo de sanção ao magistrado responsável pelo processo.

A importância da Lei de Abuso de Autoridade decorre quando, da análise da ação mais relevante da história do país (Operação Lava Jato), percebe-se o descumprimento à

29 Aqui, o termo "lei" em sentido amplo, contempla a Constituição Federal e as leis ordinárias. 
praticamente todos os artigos anteriormente mencionados, sendo que a maioria deles já está positivado - ainda que sem a possibilidade de responsabilidade pessoal do juiz - no atual ordenamento. $^{30}$

A nova lei se faz necessária, ainda, pois a atuação do Conselho Nacional de Justiça (CNJ) se mostra ineficiente e não se presta a inibir eventual abuso de autoridade. Tal fato se deve à composição do órgão fiscalizador, o qual possui quinze membros, dos quais nove pertencem à magistratura (art. 103-B, CF).

Além do que fora exposto, nos últimos anos, o que se viu, foi uma crescente atuação midiática por parte dos juízes, inclusive com posicionamentos contra legem. Repita-se, um sistema jurídico positivista passou a ser ativista (ativismo/judicialização da política) e, atualmente, é possível chamá-lo de político (politização da justiça). ${ }^{31}$

Garapon, há mais de uma década, já alertava para o fato de que esta alquimia duvidosa entre justiça e mídia assinala uma profunda desordem da democracia. A mídia desmonta a própria base da instituição judiciária, abalando a organização ritual do processo. A igualdade de armas não existe na mídia. Ela oferece um prêmio àquele que não só conta a melhor história, mas também a conta melhor. Ela reforça o efeito de verdade em detrimento da verdade; a sedução, em detrimento da argumentação. ${ }^{32}$

No Poder Judiciário não há uma leitura moral da Constituição e das leis, como defende,

\footnotetext{
${ }^{30}$ Como exemplo, tem-se o dever de motivação previsto no art. 93, IX, da Constituição Federal. Ainda, a impossibilidade de divulgação de gravação sem relação com a prova que se pretende produzir no processo (Lei $\mathrm{n}^{\circ}$ 9.296/96).

${ }^{31}$ Como exemplo é possível citar um juiz do $3^{\text {o }}$ Tribunal do Júri do Estado do Rio de Janeiro, que concedeu liberdade a dois policiais militares presos em flagrante por conta de homicídio, invocando explicitamente em sua decisão a "voz das ruas". Cf.: Autos no 007630612.2017.8.19.0001. Juiz Alexandre Abrahão Dias Teixeira. ${ }^{32}$ GARAPON, Antoine. Op. cit., p. 79.
}

por exemplo, Ronald Dworkin, ${ }^{33}$ mas sim uma leitura com fulcro na moralidade pública, a qual é volátil e dependente da exposição da mídia. Juízes utilizam, por vezes, da doutrina utilitarista, ${ }^{34}$ sob o enfoque de estar cumprindo aos anseios da sociedade. Prova disso foi $o$ discurso apresentado pela presidente do Supremo Tribunal Federal, Cármen Lúcia, quando do encerramento das atividades do primeiro semestre de 2017:

O clamor por justiça que hoje se ouve em todos os cantos do país não será ignorado em qualquer decisão desta Casa. As vozes dos que nos

${ }^{33}$ De acordo com Dworkin, a Constituição está permeada de direitos descritos de maneira demasiadamente vaga e abstrata. Tendo em vista tal situação, sugere que estes sejam interpretados com fundamento em uma leitura do moral do texto constitucional. Esta leitura moral implica que todos os operadores do direito façam uma leitura do texto constitucional com referência a princípios morais de decência e justiça. $\mathrm{O}$ autor defende que a leitura moral leva em consideração que a linguagem nem sempre logra êxito em alcançar a finalidade querida, e que esta leitura deve respeitar a evolução histórica da sociedade, e também o que o legislador quis dizer. A história é um elemento essencial para esse projeto porque, para saber o que uma pessoa quis dizer quando disse alguma coisa, temos que saber algo acerca das circunstâncias em que ela se encontrava quando disse aquilo. Assim, ao interpretar o texto deve se levar em consideração não somente o que os autores quiseram dizer, mas também a prática jurídica do passado. Em suma, a interpretação moral tem dois limites: através da história, entender o que eles queriam dizer e não as outras intenções que tinham; exigência de uma integridade constitucional, isto é, o juiz não pode dizer que a constituição expressa suas convicções pessoais. (DWORKIN, Ronald. $O$ direito da liberdade: a leitura moral da Constituição norte-americana. São Paulo: Martins Fontes, 2006, p. 10-17).

${ }^{34} \mathrm{O}$ utilitarismo é uma doutrina ética que insiste no fato de que devemos considerar o bem-estar de todos e não de uma única pessoa. "A vulnerabilidade mais flagrante do utilitarismo, muitos argumentam, é que ele não consegue respeitar os direitos individuais. Ao considerar apenas a soma das satisfações, pode ser muito cruel com o indivíduo isolado. Para o utilitarista, os indivíduos têm importância, mas apenas enquanto as preferências de cada um forem consideradas em conjunto com as de todos os demais. E isso significa que a lógica utilitarista, se aplicada de forma consistente, poderia sancionar a violação do que consideramos normas fundamentais da decência e do respeito no trato humano". (SANDEL, Michael J. Justiça: o que é fazer a coisa certa. 23. ed. Rio de Janeiro: Civilização Brasileira, 2017, p. 51). 
antecederam e que velaram pela aplicação do direito com o vigor de sua toga e o brilho de seu talento, não deixam de ecoar em nossos corações. Não seremos ausentes aos que de nós esperam a atuação rigorosa para manter sua esperança de Justiça. Não seremos avaros em nossa ação para garantir a efetividade da Justiça. ${ }^{35}$

Hodiernamente, poucas são as normas que limitam a atuação dos magistrados, ainda que reste caracterizado abuso de autoridade. É importante "evitar que o bem comum da justiça seja desviado por uma nova casta de assessores tão ameaçadora para a democracia quanto os burocratas de ontem". 36

Em síntese, ao buscar uma atualização da obsoleta Lei de Abuso de Autoridade (4.898/65), o Congresso Nacional apenas procurar pautar a atuação da magistratura, conforme mandamentos da própria Constituição Federal. Não há, em um artigo sequer do projeto, fundamento que desrespeite normas já consagradas no ordenamento jurídico.

\section{CONCLUSÃO}

Após análise do trabalho é possível perceber que a jurisdição constitucional encontra-se em ebulição. Isto decorre, pois o Poder Judiciário tem sido provocado a se manifestar acerca de matérias controversas perante a sociedade e de cunho estritamente político.

Parte da doutrina defende e parte refuta uma atuação ativista do Judiciário, sobretudo em questões de políticas públicas. Alguns alegam que ao se fazer menção ao ativismo judicial, o que se está a referir é à ultrapassagem das linhas demarcatórias da função jurisdicional, em detrimento principalmente da função legislativa,

\footnotetext{
$35 \quad$ Disponível

<http://www.stf.jus.br/portal/cms/verNoticiaDetalhe.asp?i $d$ Conteudo=348346>. Acesso em: 24 jul. 2017.

${ }^{36}$ GARAPON, Antoine. Op. cit., p. 55.
}

mas, também, da função administrativa e, até mesmo, da função de governo. ${ }^{37}$

Fato é que o sistema jurídico brasileiro precisa da aprovação da lei de abuso de autoridade; sem ela, e resguardados por uma ampla independência, os juízes passarão a "governar" o país, em evidente contrariedade ao Estado Democrático de Direito. Não se pode admitir que leis sejam descumpridas ou interpretadas ao bel-prazer do magistrado, sem qualquer tipo de consequência; seja na operação Lava Jato, seja em uma simples demanda indenizatória.

Por mais utópico que pareça, precisa-se levar o Direito a sério. Talvez seja necessário refletir o Direito sob o prisma da teoria da justiça proposta por John Rawls. Para o autor, combatente da tese utilitarista que prioriza o bem comum em relação ao indivíduo, ${ }^{38}$ para que haja justiça e igualdade entre os cidadãos, devem-se acobertar as pessoas por um hipotético "véu da ignorância" onde todos estariam em uma mesma situação (posição original), sem quaisquer tipos de vantagens econômicas ou sociais. E somente desta forma seria possível descrever como o direito pode ser aplicado com efetiva equidade. ${ }^{39}$

De forma pragmática, Eros Roberto Grau ensina que "é necessário afirmar bem alto: os juízes aplicam o direito, os juízes não fazem justiça! Vamos à Faculdade de Direito aprender direito, não justiça. Justiça é como a religião, a filosofia, a história". 40 "É preciso levar o Direito

37 RAMOS, Elival da Silva. Ativismo Judicial Parâmetros dogmáticos. São Paulo: Saraiva, 2010, p. 116.

38 "Convicções intensas da maioria, caso sejam mesmo meras preferências sem sustentação nos princípios de justiça previamente estabelecidos, não têm nenhum peso". Cf.: RAWLS, John. Uma teoria da justiça. 4. ed. rev. São Paulo: Martins Fontes, 2016, p. 556.

${ }^{39}$ Ibidem, p. 541-542.

40 "Explicitando: juízes decidem (= devem decidir) não subjetivamente, de acordo com seu senso de justiça, mas aplicando o direito (a Constituição e as leis)". (GRAU, Eros Roberto. Por que tenho medo dos juízes: (a interpretação/aplicação do direito e os princípios). 8. ed. São Paulo: Malheiros, 2017, p. 21). 
a sério, o que significa libertá-lo dos grilhões da exceção e devolvê-lo ao povo, único titular da soberania". 41

Enfim, o juiz não é um auxiliar da acusação. O seu papel não é demonstrar a todo o custo a culpa do acusado que lhe é apresentado. É preciso deixar claro: devido processo legal não existe para defender bandido; existe para impedir que $o$ Estado se torne o bandido.

${ }^{41}$ VALIM, Rafael. Estado de exceção: a forma jurídica do neoliberalismo. São Paulo: Editora Contracorrente, 2017, p. 56. 


\section{REFERÊNCIAS}

ACKERMAN, Bruce. A nova separação de poderes. Tradução de Isabelle Maria Campos Vasconcelos e Eliana Valadares Santos. Rio de Janeiro: Lumen Juris, 2009.

BARBOZA, Estefânia Maria de Queiroz; KOZICKI, Katya. Judicialização da política e controle judicial de políticas públicas. Rev. direito GV [online], v. 8, n. 1, p. 59-85, 2012.

BARROSO, Luís Roberto. O controle de constitucionalidade no direito brasileiro. 6 . ed. rev. e atual. São Paulo: Saraiva, 2012.

BONAVIDES, Paulo. Ciência política. 10. ed. 13. tiragem. São Paulo: Malheiros, 2004.

BRASIL. Constituição da República Federativa do Brasil de 1988. Disponível em: <http://www.planalto.gov.br/ccivil_03/constituicao/constituicao.htm>. Acesso em: 05 dez. 2017.

- Lei Complementar $\mathrm{n}^{\mathrm{o}}$ 35, de 14 de março de 1979. Disponível em:

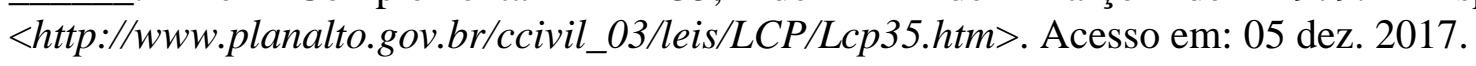

- Projeto de Lei da Câmara dos Deputados $n^{\circ}$ 7596, de 2017. Disponível em: $\langle$ http://www.camara.gov.br/proposicoesWeb/fichadetramitacao?idProposicao $=2136580\rangle$. Acesso em: 05 dez. 2017.

Projeto de Lei do Senado $\mathrm{n}^{\mathrm{o}}$ 85, de 2017. Disponível em: <https://www25.senado.leg.br/web/atividade/materias/-/materia/128545>. Acesso em: 05 dez. 2017.

CAPPELLETTI, Mauro. Juízes irresponsáveis? Porto Alegre: Sérgio Antonio Fabris Editor, 1989.

Juízes legisladores? Porto Alegre: Sérgio Antonio Fabris Editor, 1999.

CANELA JUNIOR, Osvaldo. Controle judicial de políticas públicas. São Paulo: Saraiva, 2011.

CLÈVE, Clèmerson Merlin. Atividade legislativa do Poder Executivo. 3. ed. rev. atual. e ampl. São Paulo: Revista dos Tribunais, 2011.

DWORKIN, Ronald. O direito da liberdade: a leitura moral da Constituição norte-americana. São Paulo: Martins Fontes, 2006.

GARAPON, Antoine. O juiz e a democracia: o guardião das promessas. 2. ed. Rio de Janeiro: Revan, 2001.

GRAU, Eros Roberto. Por que tenho medo dos juízes: (a interpretação/aplicação do direito e os princípios). 8. ed. São Paulo: Malheiros, 2017.

HAMILTON, Alexander; JAY, John; MADISON, James. O Federalista. 2. ed. Campinas: Russel Editores, 2005.

HIRSCHL, Ran. Towards juristocracy: the origins and consequences of the new constitutionalism. 
Harvard University Press, 2007.

MONTESQUIEU, Charles de Secondat, Barão de. O espírito das leis. 9. ed. Tradução de Pedro Vieira Mota. São Paulo: Saraiva, 2008.

RAMOS, Elival da Silva. Ativismo Judicial - Parâmetros dogmáticos. São Paulo: Saraiva, 2010.

RAWLS, John. Uma teoria da justiça. 4. ed. rev. São Paulo: Martins Fontes, 2016.

RUSSELL, Peter H. Toward a general theory of judicial independence. Judicial independence in the age of democracy: critical perspectives from around the world. The University Press of Virginia, 2001.

SANDEL, Michael J. Justiça: o que é fazer a coisa certa. 23. ed. Rio de Janeiro: Civilização Brasileira, 2017.

SERRANO, Pedro Estevam Alves Pinto. Autoritarismo e golpes na América Latina: breve ensaio sobre jurisdição e exceção. São Paulo: Alameda, 2016.

VALIM, Rafael. Estado de exceção: a forma jurídica do neoliberalismo. São Paulo: Editora Contracorrente, 2017.

Recebido em: 25/09/2017

Aceito em: 10/12/2017 
